\title{
Vivência de uma Filha-Cuidadora ao Acompanhar Sua Mãe no Processo de Fim de Vida e Morte
}

\author{
Fujisaka, Ana Paula; Kovács, Maria Júlia \\ Instituto de Psicologia da USP — anafjk@usp.br
}

Introdução: com os crescentes avanços científicos e tecnológicos, a expectativa de vida da população mundial tem aumentado, assim há cada vez mais idosos e as doenças crônicas, próprias do envelhecimento, têm se feito mais presentes. Além disso, pessoas de quaisquer faixas etárias têm sobrevivido por mais tempo a doenças graves e/ou acidentes, que antes eram mais rapidamente letais e, muitas vezes, junto à sobrevida tem se somado os sintomas incapacitantes. Dessa maneira, as mudanças nos perfis demográficos e epidemiológicos da população mundial têm aumentado a demanda por cuidados. a maior parte desses cuidados é realizada por familiares mais próximos, que têm acompanhado por mais tempo seus entes queridos no fim da vida e no processo de morrer. Esse cuidar/acompanhar na maioria das vezes gera sofrimento e adoecimentos, que ainda podem ser agravados por muitas dúvidas e anseios advindos da situação. Partindo desse cenário, o trabalho descrito a seguir foi realizado a partir da experiência de L., uma mulher de 52 anos, que foi a cuidadora principal de sua mãe, diagnosticada com câncer de mama em dezembro/2004 e falecida em março/2010, em decorrência da doença, aos 67 anos. Sua experiência é apresentada a seguir sob a forma de estudo de caso. Objetivo: compreender a experiência de uma filha-cuidadora, que cuidou/acompanhou sua mãe em seu processo de fim de vida e morte em decorrência de um câncer e seus desdobramentos. Método: a escolha do método para este trabalho foi o fenomenológico. Foram realizadas duas entrevistas individuais abertas com a participante. a primeira entrevista inicialmente partiu da pergunta: "como foi para você ter vivido a perda de sua mãe?", e a segunda entrevista foi uma continuidade do depoimento. Análise: a partir do discurso de L., foi possível destacar as seguintes unidades de significado: sendo a cuidadora principal; relacionando-se com a mãe; relacionando-se com os outros familiares; relacionando-se com os profissionais de saúde; lidando com a ambiguidade dos sentimentos; vivenciando o luto antes da morte; vivenciando o luto após a morte; lidando com a própria finitude. Considerações finais: observando as unidades de significado que surgiram no discurso dessa filha-cuidadora, é possível destacar que quando um paciente com doença em estágio avançado é tratado/cuidado, faz-se bastante importante englobar nesses cuidados também sua família. a família, especialmente o cuidador principal, é fortemente afetada pela doença e seus desdobramentos, podendo também vir a adoecer física e/ou emocionalmente. o esgotamento e o luto complicado são algumas dessas possibilidades de adoecimento. Nesse sentido, a boa relação profissional de saúde-paciente-família, ou seja, aquela em que há acessibilidade e confiança, pode servir como fator protetor ao adoecimento do familiar.

Fujisaka, Ana Paula; Kovács, Maria Júlia. Vivência de uma Filha-Cuidadora ao Acompanhar Sua Mãe no Processo de Fim de Vida e Morte. In: Anais do Congresso Internacional de Humanidades \& Humanização em Saúde [= Blucher Medical Proceedings, num.2, vol.1]. São Paulo: Editora Blucher, 2014. ISSN 2357-7282 DOI 10.5151/medpro-cihhs-10598 